International Journal of Instruction e-ISSN: 1308-1470 • www.e-iji.net

Article submission code: 20200424212804

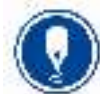

January $2021 \bullet$ Vol.14, No.1

p-ISSN: 1694-609X

pp. 1019-1034

Received: 24/04/2020

Revision: 17/08/2020
Accepted: 08/09/2020

OnlineFirst: 16/12/2020

\title{
Classroom Management Skills among Kindergarten Teachers as related to Emotional Intelligence and Self-Efficacy
}

\section{Qutaiba Agbaria}

PhD., Al-Qasemi College, Israel, qutaiba100psych@yahoo.com

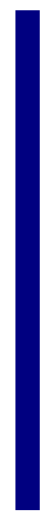

The purpose of the current study was to examine emotional intelligence and selfefficacy as predictors of classroom management skills among Arab kindergarten teachers in Israel. The study was conducted using quantitative methods. The data was collected from 337 kindergarten teachers (of students aged 3-6) who were selected using a convenience sample. Three questionnaires were used with the teachers. The findings indicated positive correlations between emotional intelligence and self-efficacy with classroom management skills $(\mathrm{r}=.65, \mathrm{p}<.01)$ and self-efficacy with classroom management skills ( $\mathrm{r}=.59, \mathrm{p}<.01)$ among Arab kindergarten teachers in Israel. The main contribution of the present study is its approach in examining the relationship of emotional intelligence and self-efficacy to the classroom management skills of teachers, specifically within the context of early childhood in Arab society in Israel, besides too the importance of teachers' self-resources in the prediction of classroom management skills.

Keywords: emotional intelligence, self-efficacy, classroom management, kindergarten teachers, classroom management skills

\section{INTRODUCTION}

The educational system sees kindergarten teaching staff as vital educational leaders and challenges them to act as principal educators in the motivation of children to achieve classroom management. This task is all the more challenging due to the rise in behavioral problems in kindergarten children. Estimates range from 5\% to $26 \%$ for the number of children demonstrating serious social, emotional and academic challenges (Brauner \& Stephens, 2006). The new reforms in Israel's educational system emphasize the importance of developing emotional, behavioral and cognitive skills among for children. This reality demands that teachers acquire more social and emotional skills in order to deal with this complexity.

A review of the literature shows that several studies have been conducted on the subjects of emotional intelligence, self-efficacy, and classroom management, although very few of them consider the connections between them. preschool teachers' self-efficacy has been shown to be a significant predictor of classroom quality and children's gains in literacy (Justice et al., 2008) as well as effective classroom management (Klassen \&

Citation: Agbaria, Q. (2021). Classroom Management Skills among Kindergarten Teachers as related to Emotional Intelligence and Self-Efficacy. International Journal of Instruction, 14(1), 1019-1034. https://doi.org/10.29333/iji.2021.14160a 
Chiu, 2010). With the apparent value of preschool teachers' sense of efficacy, it is surprising that research examining teachers' sense of efficacy remains limited. Theoretical models of self-efficacy posit that it is context specific and indicate that teacher self-efficacy can be influenced and shaped by a number of contextual variables in school settings (Bandura, 1986). According to emotional intelligence, a review of the literature shows that several studies have been conducted on the subject of emotional intelligence and classroom management although very few of them consider the connection between them. In particular, there are very few studies who have especially those that examined the relationship between emotional intelligence and management skills among kindergarten teachers. Most of the studies have been conducted in Western and Jewish societies, and few of the studies were conducted among kindergarten teachers within Israeli Arab society In particular, very few studies have examined the contribution of emotional intelligence and self-efficacy on enhancing the classroom management skills of kindergarten teachers (Hongbiao, 2015; Ramana 2013). Most of these studies have been conducted in Western and Jewish societies, and there are no studies of kindergarten teachers in Israeli-Arab society. This study will contribute to the current literature by examining the role of teachers' self-resources as predictors of classroom management among Arab kindergarten teachers in Israel.

This study provides a window into the components of the variables and concentrates on the need to understand the processes kindergarten teachers undergo, both emotionally and functionally, in managing their classrooms. Regarding the cultural context of the study, Arab society in Israel is seen as a collective society on an individualismcollectivism continuum (Dwairy, 2004). In recent years, Arab society in Israel has been undergoing changes in areas such as the changing status of the father as head of family, the weakening of the status of the clan and the extended family, the strengthening of education and of higher education, and budding changes in the status of women (Al-Haj, 1989, 1995). These changes are reflected in teachers' attitudes toward the perception of their role. Within this changing society, kindergarten education has become increasingly important, and research into its many variables is therefore crucial. The first objective of the present study focuses on examining the levels of emotional intelligence, self-efficacy and classroom management skills among Arab kindergarten teachers in Israel. The second objective focuses on examining the contribution of emotional intelligence skills and self-efficacy in predicting classroom management skills among the same Arab kindergarten teachers in Israel. The present study has two hypotheses: A significant positive correlation will be found between emotional intelligence and classroom management skills among Arab kindergarten teachers; a significant positive correlation will be found between self efficacy and classroom management skills among Arab kindergarten teachers. 


\section{Theoretical Background}

\section{Classroom Management}

The concept of classroom management is generally defined by Emmer and Stough (2001) as the activities used by teachers to organize the educational classroom environment, imposing order and encouraging student cooperation in dealing with disciplinary problems. Teacher difficulties in managing the classroom may be harmful and reduce students' motivation to learn and participate, and even increases the risk of classroom disciplinary problems (Webster-Stratton, Reinke, Herman \& Newcomer, 2011). Consistent with Emmer and Stough's (2001) definition of classroom management, Evertson and Weinstein (2006) adds that classroom management also considers the interactions between teachers and students in the form of actions taken by teachers to create an environment supportive of academic studies in the face of the social and emotional obstacles of students.

Classroom management has been researched both in Israel and abroad. Consistent throughout the literature is the conclusion that effective classroom management significantly contributes to increased student interest in their studies (Kunter, Baumert \& Koller, 2007), effective discipline management, student control, and to the study of the teacher-student relationships within the classroom (Allen, 2010). The difficulties teachers have in managing the classroom may be potentially harmful and reduce students' motivation to learn and collaborate, and even increase the risk of classroom discipline problems (Webster-Stratton, Reinke, Herman \& Newcomer, 2011).

In the few studies conducted on classroom management in Israel, Avigdor (2010) points to the lack of training and experience among the pedagogical instructors in this field, while Yariv, Simon, and Avigdor (2011) adds that there is an absence of systematic instruction and teacher training in classroom management. Kfir and Bachar (2002) maintain that a good teacher is one who takes into account the goals of education and teaching, the nature of different learning topics, a variety of learning materials, teaching methods in general, and the differences between students. In particular, Al-Amri (2009) describes the good teacher as a person who loves their profession, is modest, assertive, stable and balanced, kempt, smart, knows their students well and understands them, is knowledgeable, educated, punctual, sociable, courteous with students, devoted, respectful of students, has the ability to manage a classroom, gives his students an opportunity to express their opinions, listens more than speaks, encourages, has a sense of humor, and has the ability to translate theoretical material into practice. All of these characteristics can improve the instructional process and make it more effective.

The following three models that form the basis of classroom management were found in the research literature: training teachers to manage behavior within the classroom, fair outcomes model, and effective teacher training. The first of these was developed in the 1979s by Canter (1979) under the designation "assertive discipline." A few years later this approach was expanded, following Madeleine Canter's work with children who have behavioral disorders (Canter, 1979). What characterizes this approach is its primary focus on punishment and reward. The second model (fair outcomes), which was 
drafted by Dreikurs and Grey (1968), was based on the work of German psychiatrist Alfred Adler. This model is centered on the idea that students' unacceptable behavior is a result of dissatisfaction with the level of attention given to their needs.

The third model (effective teacher training) was developed by Gordon (1977) and presents an effective classroom management model to assist in transferring management responsibility to students. Gordon emphasizes the importance of teaching students to regulate and manage their behavior individually, as well as shedding light on the value of motivation and inner motivation, and encouraging the teacher to use the "IMESSAGE" method, which focuses on the feelings of the person speaking rather than on the student's mistakes (Edwards, 2004).

Classroom management is a complex subject, and it can be seen that the abovementioned models emphasize the importance of the actions taken by the teachers, which is in turn dependent on the many skills teaching staff need in order to achieve effective classroom management, including the quality of teaching, the ability to effectively organize the classroom, and a variety of other social and emotional factors contributing to the formation of an effective classroom learning environment.

\section{Emotional Intelligence and classroom management}

Mayer, Salovey and Caruso (2000) view emotional intelligence as being a part of social intelligence and define it as the ability of individuals to perceive emotions between themselves and others as well as within themselves. They describe how a more accurate understanding of emotions leads to more effective problem-solving in a person's emotional life, such as understanding and expressing feelings, processing emotions and thoughts, regulating emotions, and processing and understanding emotions with regard to the emotions of others. Bar-On (2006) defines emotional intelligence as an array of abilities, competencies, and emotional and social skills that enable people to cope with the demands of life and to be more effective in their personal and social lives. A wellknown researcher, Goleman (1996), views emotional intelligence as a learned system of skills that can have a profound impact on a person's social life.

After reviewing the literature, there is clearly a link between emotional intelligence and classroom management. Hargreaves (1998) claims that learning is an emotional act, with emotion playing an integral role in the interactions between students and teachers. One of the studies conducted to examine the relationship between emotional intelligence and education was carried out in China among 1,281 teachers. One of the study's findings indicated a positive correlation between the level of emotional intelligence and job satisfaction among teachers (Hongbiao, 2015). In the same context, Ramana (2013) found that teachers with high emotional intelligence tend to be more caring toward their students, become more familiar with their needs, and do better at responding accordingly. This attention teachers give to students helps reduce unacceptable student behaviors and even helps them work harder in achieving higher educational goals and academic performance. 
There are, however, few existing studies discussing the relationship between classroom management skills and emotional intelligence among kindergarten teachers, and even fewer focused on Arab populations.

\section{Self-efficacy and classroom management}

Bandura (1977) defined perceived self-efficacy as "the beliefs in one's capabilities to organize and execute the courses of action required to produce given attainments" (p. 3). Self-efficacy is a future-oriented belief about the level of competence a person expects he or she will display in a given situation. Self-efficacy beliefs, according to Bandura, "influence thought patterns and emotions that enable actions in which people expend substantial effort in pursuit of goals, persist in the face of adversity, rebound from temporary setbacks, and exercise some control over events that affect their lives" (p. 4). In this context, an individual's conviction that they can orchestrate the necessary actions to perform a given task is an efficacy expectation.

Social cognitive theory proposes a second kind of expectation called "outcome expectancy," which is the individual's estimate of the likely consequences of performing a given task at the expected level of competence (Bandura, 1986). According to social cognitive theory, personal factors and context interact through the process of reciprocal determination (Bandura, 1986, 1997). Self-efficacy, therefore, is influenced by both personal and contextual factors. Based on social cognitive theory, teacher self-efficacy may be conceptualized as individual teachers' beliefs in their own ability to plan, organize, and carry out the activities required to attain given educational goals (Skaalvik \& Skaalvik, 2010). An individual teacher may also have beliefs about both the ability of the team and of the faculty of teachers at the school to perform at a level that produces successful outcomes for students (Skaalvik \& Skaalvik, 2010). Such beliefs represent perceived collective teacher efficacy (Bandura, 1997; Goddard \& Goddard, 2001; Goddard, Hoy, \& Woolfolk Hoy, 2000).

Several studies have been conducted to examine the relationship between teacher selfefficacy and classroom management. One study that examined this correlation among preschool children in Turkey found a significant positive correlation between teachers' classroom management skills and their self-efficacy beliefs. It can be said that the teachers with stronger self-efficacy beliefs draw attention to the lesson, solve students' problems, behave democratically, obey rules and expectations, and interact with students better than others (Kayabaşi, Yeniceli, Ataman, Şahin, \& Nacar, 2017; Klassen et al., 2011). Another study in Jordan found that teacher self-efficacy has a positive correlation with each of several different classroom management styles as well as classroom management overall (Abu-Tineh, Khasawneh, \& Khalaileh, 2011).

One significant meta-study synthesized 40 years of teacher self-efficacy (TSE) research to explore the effects of TSE on the quality of classroom processes, students' academic adjustment, and teachers' psychological well-being. Via a criteria-based review approach, 165 eligible articles were included for analysis. Results suggest that TSE shows positive links with students' academic adjustment, patterns of teacher behavior and practices related to classroom quality, as well as factors underlying teachers' 
psychological well-being, such as personal accomplishment, job satisfaction, and commitment. Negative associations were found between TSE and burnout factors. A small number of the studies indicated indirect effects between TSE and academic adjustment through instructional support, and between TSE and psychological wellbeing through classroom organization (Zee \& Koomen, 2016).

In another study that examined the long-term effects of teacher self-efficacy on instructional quality in the classroom, findings indicated teacher self-efficacy is a longterm predictor of their mastery goal orientation and three dimensions of instructional quality, including supportive classroom climate, effective classroom management, and cognitive activation (Künsting, Neuber, \& Lipowsky, 2016). There is, however, a lack of studies dealing with this correlation in relation to Israel's Arab kindergarten teachers, a population with unique ethnic, social and cultural characteristics.

In summary, both emotional intelligence and self-efficacy have been identified in the literature as factors affecting classroom management skills in early childhood teachers, which may be a major source of support and nurturing or of stress and difficulty, during classroom activity in early childhood education kindergarten. In addition, there is a mutual influence of variables on the development of emotional, social and academic skills of both the teacher and the child, due to their interactions within the classroom. The literature also reflects a lack of studies investigating the contribution of emotional intelligence and self-efficacy among kindergarten teachers in predicting effective class management skills in early childhood, and especially in Israeli-Arab society.

\section{METHOD}

\section{Participants}

A total of 337 early childhood teachers from the predominantly Arab sector of northern Israel participated in the study, selected using a convenience sample. Table 1

Table 1

Sample distribution according to demographic variables

\begin{tabular}{llll}
\hline Variable & Categories & N & Percent \\
\hline Family status & Married & 250 & 74 \\
\cline { 2 - 4 } & Non Married & 87 & 26 \\
\hline \multirow{2}{*}{ Age } & $22-30$ & 171 & 51 \\
\cline { 2 - 4 } & $31-40$ & 100 & 29 \\
\cline { 2 - 4 } & $41+$ & 66 & 20 \\
\hline \multirow{2}{*}{$\begin{array}{l}\text { Educational } \\
\text { level }\end{array}$} & B.A & 290 & 86 \\
\cline { 2 - 4 } $\begin{array}{l}\text { Educational } \\
\text { framework }\end{array}$ & M.A & 47 & 14 \\
\cline { 2 - 4 } & Pre-Kindergarten & 152 & 55 \\
\hline
\end{tabular}




\section{Tools}

Three tools used to test the study variables:

Emotional Intelligence Questionnaire: The questionnaire consists of 36 statements (AlUqayshi, 2004), with responses from 1-5 on a Likert scale where $1=$ very opposed, and $5=$ in agreement. The developer presented the questionnaire to four experts who confirmed it and reported internal reliability of $\alpha=.80$ on the Cronbach Index. The questionnaire measures five factors: self-awareness; emotional thinking; empathy; calm mood; and the art of relationships. There are 7 self-awareness statements such as "When I plan to do something, I know that I can do it." An example of one of the 7 Emotional thinking statements is "When there is something that bothers me, I know how to discern the problem that is harmful to me." Among the 8 empathy statements, an example is "It's easy for me to understand the feelings of others." Calm mood is assessed by 7 statements, such as "I feel there are things in life worth experiencing." Finally, there are 7 art of relationships statements, such as "I have the ability to convince others and to influence them." For the current study, Cronbach Alpha coefficients were calculated for the questionnaire and the various measurements of the Emotional Intelligence questionnaire, and the reliability values were as follows: general emotional intelligence $\alpha=0.79$, self-awareness $\alpha=0.76$, emotional thinking $\alpha=0.70$, empathy $\alpha=0.76$, calm $\operatorname{mood} \alpha=0.77$, art of relationships $\alpha=0.78$

Teacher self-efficacy: Teacher self-efficacy was measured by the 24-item long version of the teacher self-efficacy scale (Tschannen-Moran \& Woolfolk Hoy, 2001). Each item was rated on a 9-point Likert scale (where $1=$ strongly disagree and $9=$ strongly agree). Three domains of teacher self-efficacy comprise the TSES: (a) efficacy for instructional strategies, (b) efficacy for classroom management, and (c) efficacy for student engagement. In previous empirical studies of preschool teacher self-efficacy, the three subscales demonstrated strong reliability and evidence of validity (Brown, Jones, \& Leigh, 2005; Klassen \& Chiu, 2010; Tschannen-Moran, \& Woolfolk Hoy, 2001; 2007). Specifically, Cronbach's alpha for the three subscales we as follows: instruction $\alpha=.94$, management $\alpha=.91$, and engagement $\alpha=.87$ (Tschannen-Moran \& Woolfolk Hoy, 2001). For the current study, the following values were obtained: efficacy for instructional strategies $\alpha=.89$, efficacy for classroom management $\alpha=.85$, efficacy for student engagement $\alpha=.83$, and for the overall scale $\alpha=.84$.

Classroom Management Questionnaire: The questionnaire, developed by the University of Michigan (USA) in 1983, consists of 102 statements rated from 1-4 on a Likert scale where $1=$ not performed at all, and $4=1=$ performed at a high level. The questionnaire was reviewed by seven experts who approved it, and the items approved by the experts were included. The developer reported internal reliability of $\alpha=.98$ according to the Cronbach Index. The questionnaire measures 16 factors: organization of the educational environment; having a yearly or semester plan; lesson planning; flexibility of instructions and study assignments; flexibility and adaptability; openness toward students; encouragement; encouraging student participation; classroom management; lesson performance; involvement in the local community; evaluation; 
verbal and nonverbal communication; attributes; academic efficiency; and professional commitment. For the current study, Cronbach Alpha coefficients were calculated for the questionnaire and the various items measured. The reliability values for general classroom management was $\alpha=0.95$, and for the other factor Cronbach Alf values were high from .77 to .85 .

\section{Research Process}

After obtaining the required permits from the ministry of education, the schools in the region were contacted and questionnaires were distributed to the study participants, at which point the researcher contacted the kindergarten teachers to explain the purpose of the study and to ensure anonymity and discretion. The study included kindergarten teachers from the Arab sector in the northern region of Israel during the school year. The researcher visited the schools and kindergartens and distributed the questionnaires to kindergarten teachers after providing them with a general explanation of the study. Each kindergarten teacher filled out three different questionnaires. Ninety percent of the teachers agreed to participate.

\section{Statistical analysis}

Means, standard deviations, and maximum and minimum values for emotional intelligence, self-efficacy and classroom management were calculated first. Alpha of Cronbach calculated for the research tools. Correlations among the study's variables were then calculated. To test the research hypotheses, a series of multiple regression analyses were performed to test the prediction of emotional intelligence and selfefficacy on classroom management skills.

\section{FINDINGS}

In order to examine the levels of the study variables, means and standard deviations were calculated first, along with minimum and maximum values for emotional intelligence, self-efficacy, and classroom management as detailed in Table 2.

Table 2

Mean, standard deviation, minimum and maximum values for the study variables

\begin{tabular}{lllll}
\hline & Mean & SD & Min & Max \\
\hline Classroom management & 1.74 & 0.65 & 1 & 4 \\
\hline Emotional intelligence & 3.89 & 0.50 & 2.57 & 5 \\
\hline Self-efficacy & 5.99 & 0.51 & 1 & 7 \\
\hline
\end{tabular}

Table 2 shows that relatively high scores were obtained for the three variables. The first hypothesis focused on the relationship between emotional intelligence and classroom management. Table 3 below shows that there is a statistically significant positive correlation between emotional intelligence and classroom management $(r=.65, p<.01)$. 
Table 3

Pearson correlations for the research variables $(\mathrm{N}=337)$

\begin{tabular}{llll}
\hline & 1 & 2 & 3 \\
\hline 1. Classroom management & - & & \\
\hline 2. Emotional intelligence & $.65^{* *}$ & - & \\
\hline 3. Self-efficacy & $.59^{* *}$ & ${ }^{* *} 0.53$ & - \\
\hline$* * \mathrm{p}<.01$ & &
\end{tabular}

In the regression analysis for predicting classroom management shown in Table 4, it was found that the contribution of emotional intelligence was significant in explaining the variance in classroom management $(\mathrm{B}=.19, \mathrm{SE}=.08, \beta=.28)$.

Table 4

Multiple regression coefficients for predicting classroom management

\begin{tabular}{lllll}
\hline & $\begin{array}{l}\beta \text { ( standardized } \\
\text { coefficient })\end{array}$ & $\begin{array}{l}\text { B ( unstandardized } \\
\text { coefficient) }\end{array}$ & SE & $\mathrm{R}^{2}$ \\
\hline Total model & & & & $.34^{* *}$ \\
\hline Emotional intelligence & .28 & $.19^{* *}$ & .08 & \\
\hline Self efficacy & .32 & $.23^{* *}$ & .11 & \\
\hline
\end{tabular}

Note: $* p<.05 ; * * p<.01 ; n=337$

The second research hypothesis focused on the relationship between self-efficacy and classroom management. Table 2 above shows that there is a statistically significant positive correlation between self-efficacy and classroom management $(\mathrm{r}=.59, \mathrm{p}<.01)$, and the regression analysis for predicting classroom management in Table 3 shows that the contribution of self-efficacy was significant in explaining the variance in classroom management $(\mathrm{B}=.32, \mathrm{SE}=.11, \beta=.23)$.

\section{DISCUSSION}

The purpose of this study was to examine the contribution of emotional intelligence and self-efficacy to the classroom management skills of kindergarten teachers in Israeli-Arab society. To this end, and for the first time, these two variables were examined in the context of Israeli-Arab kindergarten teachers.

\section{Classroom Management Skills and Emotional Intelligence}

The first research hypothesis focused on the relationship between emotional intelligence and classroom management skills. The findings indicate a statistically significant positive relationship between emotional intelligence and classroom management skills, thus confirming the research hypothesis.

This finding is in line with the findings of previous studies indicating a link between classroom management effectiveness and emotional intelligence (Jensen, Skibsted \& Christensen, 2015; Kidar, 2011; Ramana, 2013; Tal, 2010). These studies also found that along with teaching ability and management skills, other crucial abilities for learning outcomes include teacher knowledge and the ability to establish interpersonal 
relationships, to feel empathy, respect, and tolerance, and to show interest in the students and in their potential.

The findings are also supported by studies showing that awareness on the part of teachers about their emotions and how to manage them plays an important role in their relationship to his students, and influences the continuity and nature of the teacher-pupil relationship (Tal, 2010). Teachers with high emotional intelligence tend to show more compassion towards their students and become more familiar with their needs and respond accordingly( Kedar, 2011). These results can be explained by the model of effective management, developed by Gordon (1977), which achieves an effective classroom management model to help transfer management responsibility to students. The mixed model of emotional-social intelligence, developed by Bar-On (2006), also helps explain the results in that teacher-pupil relations and the ability to accept and encourage students and to allow them to participate in the classroom are all built on the foundation of teachers' self-awareness, empathy and emotional management in their relationship with the students. Teachers with higher levels of emotional intelligence are better able to use emotion to focus on student behavior and to think rationally, logically and creatively during the lesson. Reliance on the emotional pattern created by teachers, out of all of their contacts with the students, allows for the creation of the core of their emotional outlook and emotional abilities. The response of teachers with emotional intelligence to student behaviors and needs provides sufficient opportunities and guidelines to handle and control teacher-student relationships within the classroom, and contributes to greater classroom management effectiveness.

\section{Classroom Management Skills and Self Efficacy}

The second research hypothesis focused on the relationship between self-efficacy and classroom management skills. The findings indicate a statistically significant positive relationship between self-efficacy and classroom management skills, thus confirming the research hypothesis. This finding is in line with the findings of previous studies indicating a link between classroom management effectiveness and teacher self-efficacy (Abu-Tineh, Khasawneh, \& Khalaileh, 2011; Kayabaşi, Yeniceli, Ataman, Şahin, \& Nacar, 2017; Künsting, Neuber, \& Lipowsky, 2016; Zee \& Koomen, 2016).

Previous empirical studies have demonstrated a positive relationship between teacher self-efficacy and student achievement. (Armor et al., 1976; Bandura, 1993; Gibson \& Dembo, 1984; Goddard \& Goodard, 2001). Teacher self-efficacy has previously been positively correlated to student gains across various academic subject areas at the elementary and middle school level, such as in English/language arts, math, and social

studies (Armor et al., 1976). Armor et al. (1976) found that teacher self-efficacy correlated to reading achievement in inner-city sixth-grade students attending public schools within urban districts in the United States. Classroom quality and best practices may at times be included by teacher self efficacy (Goddard \& Goodard, 2001). In other words, self-efficacy indirectly affects student achievement through classroom quality. To date, however, very few studies have directly explored the hypothesized correlation 
between self-efficacy and student achievement with respect to the potential moderating role of classroom quality (Guo et al., 2011, 2010).

The quality of the classroom atmosphere has been measured by two domains of the class, primarily the emotional support and instructional support domain is made up of two domains (Mashburn et al., 2008). The emotional support domain measures the extent to which teachers are emotionally engaged with their students. The instructional

support domain measures the verbal interactions between a teacher and their students. Teachers who were rated as providing instructionally supportive classroom environments did so by asking open-ended questions, engaging their children in continuous feedback loops, and used scaffolding concepts of instruction (Mashburn et al., 2008; Pianta et al., 2008). Emotional support and the instructional support domains of the class have been associated with student achievement in the empirical research conducted in the United States (Pianta et al., 2008; Pianta, La Paro, Payne, Cox, \& Bradley, 2002; Mashburn et al., 2008). Language and literacy development among preschool children is an important characteristic that has been observed to be impacted by teacher student interactions in the classroom. (Meisels, 2006).

Tschannen-Moran et al. (1998) proposed that teacher self-efficacy may impact how much effort teachers put forth in the daily educational process of educating children. Therefore, teachers with high levels of self-efficacy are more likely to "employ a pattern of strategies that minimized negative effects, and promoted an expectation of classroom situations characterized by warm interpersonal relationships and academic work" (p. 125). Another explanation may be related to the teacher beliefs in their capabilities, enabling them to explore their strengths and weakness, and helping them to be more organized and more self-aware. Therefore, it can affect their behaviors in general and their class management in specific.

\section{CONCLUSIONS}

The main contribution of the present study is its approach to the study of the relationship between emotional intelligence and self efficacy among teachers and classroom management skills, and its unique contribution is to examine this relationship in early childhood. The current findings empathize the contribution of teachers' self-resources in the prediction of classroom skills among kindergarten teachers. Beyond that, it contributes to deepen the knowledge about the importance of the relationship between emotional intelligence, self efficacy and classroom management skills among kindergarten teachers in an effort to contribute to the effectiveness of their work and to lead them through the application of future programs to give of the best of their abilities, in order to benefit their work and to experience doing their job as effectively as possible. This is the first study that conducted among this population, the findings align with other studies in western societies. This contribution is likely to have positive implications for their students. The findings of this study have shown the contribution of self efficacy and emotional intelligence in predicting between classroom management skills among kindergarten teachers. Therefore, the first practical contribution is to establish workshops for teachers in order to raise awareness among them about the importance of 
acquiring emotional intelligence in general, self-awareness and empathy and emotional management in particular, classroom in achieving management skills in the kindergarten, in particular, and in school in general.

\section{Research Limitations}

The present study does have some significant limitations. First, the sample is a convenience sample drawn from a defined geographic regions and is not a random sample. The study included 337 kindergarten teachers located in northern Israel, and as a result generalization of the results is questionable. There is a need for more research based on random sampling including more diverse strata of the Arab population.

Second, the study relies on self-reporting questionnaires for its data collection. Exclusive reliance on self-reporting can result in bias. Such a report can naturally be biased because of social desirability, meaning the desire to respond in a manner consistent with social conventions. Future studies would benefit from adding behavioral indices or external judges to add validity to the results.

Third, some of the teachers' questionnaires were sent to them through workshops and seminars, and they had a limited amount of time to fill them in, such that in the case of a lack of clarity it was not possible to respond to their questions immediately.

The study was conducted within the context of a relative deficiency in research about the Arab population in Israel, thus making it difficult to compare the current study and its findings with other research studies.

Hence, there is a need for future studies to test the research variables in early childhood with consideration of these limitations. Future studies may can focus on the cultural differences in these variables.

\section{REFERENCES}

Abu-Tineh, A. M., Khasawneh, S. A., \& Khalaileh, H. A.(2011). Teacher self-efficacy and classroom management styles in Jordanian schools. Management in Education, 25(4), 175-181.

Al-Haj, M. (1989). Social research on family lifestyles among Arabs in Israel. Journal of Comparative Family Studies, 20, 175-195.

Al-Haj, M. (1995). Kinship and modernization in developing societies: The emergence of instrumentalized kinship. Journal of Comparative Family Studies, 26, 311-328.

Al-Amri, P. (2009). The successful teacher .Jordan, Amman: Dar Osama. [In Arabic].

Allen, K. P. (2010). Classroom management, bullying, and teacher practices. The Professional Educator, 34(1),1.

Al-Uqayshi, B. (2004). Mental health as related to emotional intelligence among students. (Master Thesis), University of Baghdad. [In Arabic]. 
Armor, D., Cornroy-Oseguera, P., Cox, M., King, N., McDonnell, L., \& Pascal, A. (1976). Analysis of the school preferred reading program in selected Los Angeles minority schools (Report No. R-2007-LAUSD, ERIC Document Reproduction No. 130 243). Santa Monica, CA: Rand Corporation.

Avigdor, Y. (2010). Pedagogic guidance on disciplinary problems. (Master Thesis), Gordon College of Education, Haifa. [In Hebrew].

Bandura, A. (1977). Self-efficacy: Toward a unifying theory of behavioral change. Psychological Review, 84(2), 191-215.http://dx.doi.org/10.1037/0033-295X.84.2.191.

Bandura, A. (1986). Social foundations of thought and action: A social cognitive theory. Englewood Cliffs, NJ: Prentice-Hall.

Bandura, A. (1993). Perceived self-efficacy in cognitive development and functioning. Educational Psychologist, 28, 117-148.

Bandura, A. (1997). Self-efficacy: The exercise of control. New York: Freeman.

Bar-On, R. (2006). The Bar-On model of emotional-social intelligence (ESI) 1. Psicothema, 18, 13-25.

Brauner, C. B., \& Stephens, C. B. (2006). Estimating the prevalence of early childhood serious emotional/behavioral disorders: Challenges and recommendations. Public Health Reports, 121(3), 303-310.

Brown, S. P., Jones, E., \& Leigh, T. W. (2005). The attenuating effect of role overload on relationships linking self-efficacy and goal level to work performance. Journal of Applied Psychology, 90(5), 972.

Canter, L. (1979). Taking charge of student behavior. National Elementary Principal, $58(4), 3-36$.

Dwairy, M. (2004). Parenting styles and mental health of Palestinian-Arab adolescents in Israel. Transcultural Psychiatry, 41, 233-252.

Edwards, C. H. (2004). Classroom discipline and management. 4th ed. New York: John Wiley and Sons.

Emmer, E.T., \& Stough, L.M. (2001). Classroom management: A critical part of educational psychology. Educational Psychologist, 36, 103-112.

Evertson, C. M., \& Weinstein, C. S. (2006). Classroom Management as a Field of Inquiry. In C. M. Evertson, \& C. S. Weinstein (Eds.), Handbook of Classroom Management. Research, Practice, and Contemporary Issues (pp. 3-16). Mahwah, NJ: Lawrence Erlbaum Associates.

Gibson, S., \& Dembo, M. (1984). Teacher efficacy: a construct validation. Journal of Educational Psychology, 76, 569-582. 
Goddard, R.D. \& Goddard, Y.L. (2001). A multilevel analysis of the relationship between teacher and collective efficacy in urban schools. Teaching and Teacher Education, 17, 807-818. http://dx.doi.org/10.1016/S0742-051X(01)00032-4.

Goddard, R. D., Hoy, W. K., \&Woolfolk Hoy, A. (2000). Collective teacher efficacy: Its meaning, measure, and effect on student achievement. American Educational Research Journal, 37 (2), 479-507.

Goleman, D. (1996). Emotional Intelligence: Why It Can Matter More than IQ. New York: Bantam Books.

Gordon, T. (1977). T.E.T.: Teacher effectiveness training. New York: David McCay.

Guo, Y., Kaderavek, J. N., Piasta, S. B., Justice, L. M., \& McGinty, A. (2011). Preschool teachers' sense of community, instructional quality, and children's language and literacy gains. Early Education and Development, 22(2), 206-233.

Guo, Y., Piasta, S. B., Justice, L. M., \& Kaderavek, J. (2010). Relations among preschool teachers' self-efficacy, classroom quality and children's language and literacy gains. Teaching and Teacher Education, 26, 1094-1103.

Hargreaves, A. (1998). Emotional geographies of teaching. Teachers College Record, 103(6), 1056-1080.

Hongbiao, Y. (2015). The effect of teachers' emotional labor on teaching satisfaction: moderation of emotional intelligence. Teachers \& Teaching, 21 (7), 789-810.

Jensen, E., Skibsted, E. B., \& Christensen, M. V. (2015). Educating teachers focusing on the development of reflective and relational competencies. Educational Research for Policy and Practice, 14(3), 201-212.

Justice, L. M., Mashburn, A. J., Hamre, B. K., \& Pianta, R. C. (2008). Quality of language and literacy instruction in preschool classrooms serving at-risk pupils. Early Childhood Research Quarterly, 23, 51-68.

Kayabaşı, Y., Yeniceli, E., Ataman, E., Şahin, S., \& Nacar, N. (2017). Ortaokul Öğretmenlerinin Sınıf Yönetimi Becerileri İle Özyeterlik İnançları Arasındaki İlişki: Ankara İli Örneği. Kuramsal Eğitimbilim Dergisi, 10(2), 298-319.

Kedar, D. (2011). Emotional intelligence and humor. Humor Online, 1, 5-14. [In Hebrew].

Kfir, D., \& Bachar, S. (2002). The teaching on the way to Propecia: perception of the character of teachers in the eyes of those who engage in teaching and who are capable of engaging in it. In B. Fresco and D. Kfir (Eds.) Ongoing Dialogue: Teacher Training and Educational Practice (p. 3453). Tel Aviv: The Mofet Institute.

Klassen, R. M., \& Chiu, M. M. (2010). Effects on teachers' self-efficacy and job satisfaction: Teacher gender, years of experience, and job stress. Journal of educational Psychology, 102(3), 741. 
Klassen, R.M., Al-Dhafri, S., Hannok, W., \& Betts, S.M.(2011). Investigating preservice teacher motivation across cultures using the teachers' ten statements test. Teaching and Teacher Education, 27, 579-588.

Künsting, J., Neuber, V. \& Lipowsky, F. (2016). Teacher self-efficacy as a long-term predictor of instructional quality in the classroom. European Journal of Psychology of Education, 31(3), 299-322.

Kunter, M., Baumert, J., \& Koller, O. (2007). Effective classroom management and the development of subject-related interest. Learning and Instruction, 17(5), 494-509.

Mashburn, A. J., Pianta, R. C., Hamre, B. K., Downer, J. T., Barbarin, O., \& Bryant, D. (2008). Measures of classroom quality in prekindergarten and children's development of academic, language, and social skills. Child Development, 79(3), 732-749.

Mayer, J. D., Salovey, P., \& Caruso, D. R. (2000). Models of emotional intelligence. In R. J. Sternberg (Ed.), Handbook of Intelligence. Cambridge, New York: Cambridge University Press.

Meisels, S. J. (2006). Accountability in early childhood: No easy answers. Chicago, IL: Erikson Institute, Herr Research Center for Children and Social Policy.

Pianta, R. C., La Paro, K. M., \& Hamre, B. K. (2008). Classroom assessment scoring system: Pre-K. Baltimore, MD: Paul Brookes Publishing.

Pianta, R. C., La Paro, K. M., Payne, C., Cox, M. J., \& Bradley, R. (2002). The relation of kindergarten classroom environment to teacher, family, and school characteristics and child outcomes. The Elementary School Journal, 102(3), 225-238.

Ramana, T. V. (2013). Emotional intelligence and teacher effectiveness-analysis. Voice of Research, 2(2), 18-22.

Skaalvik, E. M., \& Skaalvik, S. (2010). Teacher self-efficacy and teacher burnout: a study of relations. Teaching and Teacher Education, 26, 1059-1069. http://dx.doi.org/10.1016/j.tate.2009.11.001.

Tal, K. (2010). Classroom moral management. Educational Counselling, 16, 152-175. [In Hebrew].

Tschannen-Moran, M., \& Hoy, A. W. (2001). Teacher efficacy: Capturing an elusive construct. Teaching and teacher education, 17(7), 783-805.

Tschannen-Moran, M., Hoy, A. W., \& Hoy, W. K. (1998). Teacher efficacy: Its meaning and measure. Review of educational research, 68(2), 202-248.

Webster-Stratton, C., Reinke, W. M., Herman, K. C., \& Newcomer, L. L. (2011). The incredible years teacher classroom management training: the methods and principles that support fidelity of training delivery. Online Submission, 40(4), 509-529. 
Yariv, A., Simon, A. and Avigdor, Y. (2011). "Far from the maddening crowd": Other views of classroom disruptions. Mifgash: Journal of Social-Educational Work, 89-110. [In Hebrew].

Zee, M., \& Koomen, H. M. (2016). Teacher self-efficacy and its effects on classroom processes, student academic adjustment, and teacher well-being: a synthesis of 40 years of research. Review of Educational Research, 86(4), 981-1015. 